\title{
KEJADIAN DIARE PADA MASYARAKAT PETERNAK SAPI PERAH
}

\author{
Redhita Fatrisia \\ Endang Sri Redjeki \\ Rara Warih Gayatri \\ Universitas Negeri Malang \\ E-mail: redhitafatrisia17@gmail.com,
}

\begin{abstract}
Diarrhea is still a global public health problem especially in developing countries like Indonesia. Diarrhea is closely related to environmental health. The purpose of this study was to determine the relationship between diarrhea occurrence with the density of flies and the management of livestock waste in dairy farmers community in Krajan Hamlet, Kemiri Village, Jabung District, Malang Regency. The type of this research is descriptive analytic with cross sectional study design. The data were collected using questionnaires, observation sheets, and measurement using fly grill and hand counter. The sample in this research is 177 dairy farmer families with sampling method using cluster random sampling. Data were analyzed by univariate and bivariate analysis using chi square test. The results showed a significant correlation between diarrhea occurrence with flies density $(p=$ $0.00)$ and there was significant correlation between diarrhea occurrence and livestock waste management $(p=0.00)$. It is suggested to the dairy farmers community to apply clean and healthy behavior, and to conduct the management and utilization of livestock waste.
\end{abstract}

Keyword : the incidence of diarrhea, fly density, the management of livestock waste

\begin{abstract}
ABSTRAK : Diare masih menjadi masalah kesehatan masyarakat dunia, terlebih di negara berkembang seperti Indonesia. Diare erat kaitannya dengan kesehatan lingkungan. Penelitian ini bertujuan untuk mengetahui hubungan antara kejadian diare dengan kepadatan lalat dan pengelolaan limbah ternak pada masyarakat peternak sapi perah di Dusun Krajan, Desa Kemiri, Kecamatan Jabung, Kabupaten Malang. Jenis penelitian adalah deskriptif analitik dengan desain studi cross sectional. Pengumpulan data menggunakan instrumen berupa kuesioner, lembar observasi, dan pengukuran menggunakan fly grill dan hand counter. Sampel pada penelitian ini adalah 177 keluarga peternak dengan metode pengambilan sampel menggunakan cluster random sampling. Data dianalisis dengan analisis univariat dan bivariat menggunakan uji chi square. Hasil penelitian menunjukkan adanya hubungan yang signifikan antara kejadian diare dengan kepadatan lalat $(\mathrm{p}=0,00)$ dan terdapat hubungan yang signifikan antara kejadian diare dengan pengelolaan limbah ternak $(\mathrm{p}=0,00)$. Disarankan kepada masyarakat peternak sapi perah untuk menerapkan Perilaku Hidup Bersih dan Sehat (PHBS), dan melakukan usaha pengelolaan dan pemanfaatan limbah ternak.
\end{abstract}

Kata Kunci : kejadian diare, kepadatan lalat, pengelolaan limbah ternak

Diare adalah suatu kondisi dimana seseorang buang air besar dengan konsistensi lembek atau cair, dengan frekuensi tiga kali atau lebih per hari atau lebih sering dari orang-orang normal (World Health Orgnisation, WHO, 2016). Diare masih menjadi masalah kesehatan masyarakat dunia khususnya di negara berkembang seperti Indonesia, karena angka morbiditas dan mortalitasnya yang masih tinggi. Menurut data Kementerian Kesehatan Republik Indonesia (Kemenkes RI) tahun 2011, diare menjadi penyebab kematian peringkat ke-13 dengan proporsi $3,5 \%$.

Lingkungan memegang pengaruh paling besar terhadap kesehatan (Notoatmodjo, 2012). Penyebab penya- 
kit diare diantaranya karakteristik masyarakat dan kesehatan lingkungan.

Menurut data Puskesmas Jabung (2014), angka kejadian diare di Desa Kemiri lebih tinggi dari rata-rata desa yang lain di Kecamatan Jabung Kabupaten Malang tahun 2014 yaitu sebanyak 104 kasus dan 38 kasus terjadi pada balita. Desa Kemiri memiliki permasalahan lingkungan terkait banyaknya peternak di wilayah tersebut. Dusun Krajan merupakan wilayah dengan jumlah populasi peternak paling banyak yaitu 365 keluarga. Pengelolaan dan pemanfaatan limbah ternak sapi yang tidak saniter mampu menjadi media yang tepat bagi tempat perindukan vektor diare, yaitu lalat.

Lalat adalah vektor mekanik berbagai penyakit (Dewi, 2007). Vektor mekanik yaitu hewan avertebrata yang menularkan penyakit tanpa disertai perubahan pada agen (Soeharsono dalam Wijayanti, 2008).

Semakin tinggi tingkat kepadatan lalat, maka semakin tinggi pula kemungkinan penyebaran penyakit diare. Hal tersebut sesuai dengan penelitian yang dilakukan oleh Manulu dkk (2012) mengenai hubungan antara kepadatan lalat dengan kejadian diare pada anak balita yang bermukim di sekitar Tempat Pembuangan Akhir (TPA) Sampah Namo Bintang, Kecamatan Pancur Batu, Kabupaten Deli Serdang. Penelitian tersebut memperlihatkan bahwa angka kepadatan lalat di rumah balita memiliki hubungan yang bermakna dengan kejadian diare.

Berdasarkan pada gambaran kejadian diare di Indonesia khususnya di Desa Kemiri Kecamatan Jabung serta faktor risiko terkait diare yakni kondisi lingkungan, maka secara umum tujuan

\section{HASIL}

Hasil penelitian mengenai kejadian diare dalam kurun waktu tiga bulan penelitian ini adalah untuk mengetahui hubungan kejadian diare dengan kepadatan lalat dan pengelolaan limbah ternak pada masyarakat peternak sapi perah di Dusun Krajan Desa Kemiri Kecamatan Jabung Kabupaten Malang.

\section{METODE}

Penelitian ini adalah penelitian observasional studi yang bersifat deskrip-tif analitik dengan desain studi cross sectional. Penelitian dilakukan pada bulan Februari-April 2017, di Dusun Krajan Desa Kemiri Kecamatan Jabung Kabupaten Malang. Populasi penelitian adalah keluarga peternak sapi perah di Dusun Krajan yang berjumlah 365 keluarga. Sampel dalam penelitian ini adalah keluarga peternak yang memelihara sapi perah di lingkungan rumah. Besar sampel dalam penelitian ini menggunakan rumus Isaac dan Michael dalam Sugiyono (2015) diperoleh jumlah sampel minimal sebanyak 177 responden. Teknik yang digunakan dalam pengambilan sampel adalah cluster random sampling. Teknik sampling tersebut dipilih dengan mempertimbangkan unit geografis yaitu pembagian wilayah Rukun Warga (RW) sebagai dasar pembagian cluster/ kelompok.

Instrumen penelitian menggunakan kuesioner, lembar observasi, dan alat penghitung kepadatan lalat yaitu fly grill dan hand counter. Data dikumpulkan dengan teknik wawancara, pengukuran dan observasi.

Pengolahan data meliputi 1) Editing data, 2) Coding data, 3) Entry data, dan 4) Cleaning data. Analisis data yang dilakukan berupa analisis univariat dan analisis bivariat dengan menggunakan uji chi square.

\section{Gambaran Kejadian Diare}

terakhir terhitung sejak pengambilan data tercantum pada Gambar 1. 


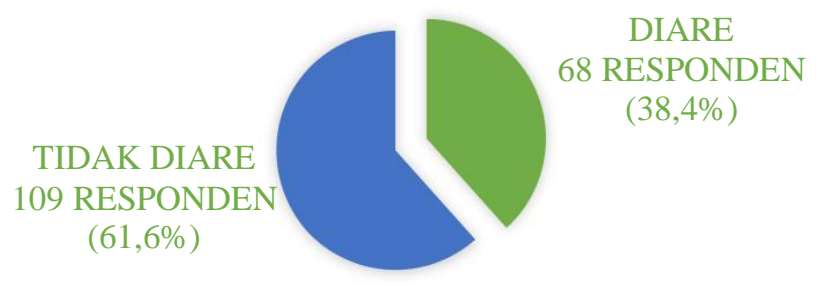

Gambar 1. Diagram ditribusi kejadian diare pada masyarakat peternak sapi perah

Hasil analisis distribusi kejadian diare pada peternak sapi perah ditampilkan pada Gambar 1, terdapat 68

\section{Gambaran Kepadatan Lalat}

Hasil penelitian berupa pengu-

kuran kepadatan lalat di kandang sapi keluarga $(38,4 \%)$ pernah mengalami kejadian diare. Sedangkan 109 keluarga $(61,6 \%)$ tidak pernah mengalami diare. perah menggunakan fly grill didapatkan hasil sesuai Tabel 1 .

Tabel 1 Kepadatan Lalat di kandang ternak sapi perah

\begin{tabular}{lcc}
\hline \multicolumn{1}{c}{ Kepadatan Lalat } & Frekuensi & Persentase $(\%)$ \\
\hline Sangat Tinggi $(\geq 21$ ekor) & 17 & 9,6 \\
Tinggi (6-20 ekor) & 35 & 19,8 \\
Sedang (3-5 ekor) & 39 & 22,0 \\
Rendah (0-2 ekor) & 86 & 48,6 \\
\hline Jumlah & 177 & 100,0 \\
\hline
\end{tabular}

Berdasarkan Tabel 1 dapat diketahui bahwa sebagian besar rumah yang memelihara sapi perah memiliki kepadatan lalat yang rendah yakni sebesar 86 rumah atau $48,6 \%$ dari total responden, untuk rumah dengan kepadatan lalat sedang (3-5 ekor) mencapai 39 rumah, 35 rumah dengan kepadatan lalat tinggi (6-20 ekor) dan 17 rumah dengan kepadatan lalat sangat tinggi.

\section{Gambaran Pengelolaan Limbah Ternak \\ Gambaran mengenai ditribusi pengelolaan limbah ternak di Dusun Krajan dalam penelitian ini dapat dilihat pada Tabel 2.}

Tabel 2 Pengelolaan limbah ternak di Dusun Krajan Desa Kemiri Kecamatan Jabung

\begin{tabular}{lcc}
\multicolumn{1}{c}{ Pengelolaan Limbah Ternak } & Frekuensi & Persentase (\%) \\
\hline Tidak & 107 & 60,5 \\
Ya & 70 & 39,5 \\
\hline Jumlah & 177 & 100,0 \\
\hline
\end{tabular}

Berdasarkan Tabel 2 diketahui bahwa sebagian besar peternak $(60,5 \%$ atau 107 responden) tidak mengelola limbah ternaknya dengan baik, sementara 70 peternak $(39,5 \%)$ mengelola limbah ternak dengan baik.
Hubungan Kejadian Diare dengan Kepadatan Lalat

Hasil uji statstik menggunakan chi square mengenai hubungan kejadian diare dengan kepadatan lalat dijabarkan pada Tabel 3. 
Tabel 3 Distribusi peternak sapi perah menurut hubungan kejadian diare dengan kepadatan lalat di Dusun Krajan Desa Kemiri Kecamatan Jabung

\begin{tabular}{|c|c|c|c|c|c|c|c|c|}
\hline \multirow{3}{*}{$\begin{array}{l}\text { Kepadatan } \\
\text { Lalat }\end{array}$} & \multicolumn{4}{|c|}{ Kejadian Diare } & \multirow{2}{*}{\multicolumn{2}{|c|}{ Total }} & \multirow{3}{*}{ PR } & \multirow{3}{*}{ P Value } \\
\hline & \multicolumn{2}{|c|}{$\mathrm{Ya}$} & \multicolumn{2}{|c|}{ Tidak } & & & & \\
\hline & $\mathrm{N}$ & $\%$ & $\mathrm{~N}$ & $\%$ & $\mathrm{~N}$ & $\%$ & & \\
\hline Sangat Tinggi & 14 & 82,4 & 3 & 17,6 & 17 & 100 & $\begin{array}{c}20,41 \\
(5,24-79,55)\end{array}$ & 0,00 \\
\hline Tinggi & 27 & 77,1 & 8 & 22,9 & 35 & 100 & $\begin{array}{c}14,76 \\
(5,66-38,48)\end{array}$ & 0,00 \\
\hline Sedang & 11 & 28,2 & 28 & 71,8 & 39 & 100 & $\begin{array}{c}1,71 \\
(0,71-4,16)\end{array}$ & 0,33 \\
\hline Rendah & 16 & 18,6 & 70 & 81,4 & 86 & 100 & Pembanding & \\
\hline Total & 68 & 38,4 & 109 & 61,6 & 177 & 100 & & \\
\hline
\end{tabular}

Hasil uji chi square dengan kepadatan lalat rendah sebagai pembanding yang terdapat pada Tabel 4 dapat diketahui bahwa terdapat hubungan yang signifikan antara kepadatan lalat sangat tinggi dan kepadatan lalat tinggi dengan kejadian diare $(P$ value $<0,05)$. Sementara kepadatan lalat sedang tidak berhubungan dengan kejadian diare $(P$ value $>0,05)$. Semakin padat populasi lalat maka semakin terdapat hubungan yang signifikan dengan kejadian diare sehingga risiko untuk terkena diare menjadi lebih besar, dibuktikan dengan nilai Prevalence Ratio (PR) yang semakin besar.

\section{Hubungan Kejadian Diare dengan Pengelolaan Limbah Ternak}

Hasil uji statstik menggunakan chi square mengenai hubungan kejadian diare dengan pengelolaan limbah ternak dijabarkan pada Tabel 4.

Tabel 4 Distribusi peternak sapi perah menurut hubungan kejadian diare dengan pengelolaan limbah ternak di Dusun Krajan Desa Kemiri Kecamatan Jabung

\begin{tabular}{|c|c|c|c|c|c|c|c|c|}
\hline \multirow{3}{*}{$\begin{array}{c}\text { Pengelolaan } \\
\text { Limbah Ternak }\end{array}$} & \multicolumn{4}{|c|}{ Kejadian Diare } & \multirow{2}{*}{\multicolumn{2}{|c|}{ Total }} & \multirow{3}{*}{ PR } & \multirow{3}{*}{ P Value } \\
\hline & \multicolumn{2}{|c|}{$\mathrm{Ya}$} & \multicolumn{2}{|c|}{ Tidak } & & & & \\
\hline & $\mathrm{N}$ & $\%$ & $\mathrm{~N}$ & $\%$ & $\mathrm{~N}$ & $\%$ & & \\
\hline Tidak & 53 & 49,5 & 54 & 50,5 & 107 & 100 & 3,59 & \\
\hline $\mathrm{Ya}$ & 15 & 21,4 & 55 & 78,6 & 70 & 100 & $(1,81-$ & 0,00 \\
\hline Total & 68 & 38,4 & 109 & 61,6 & 177 & 100 & $7,14)$ & \\
\hline
\end{tabular}

Berdasarkan hasil penelitian dalam Tabel 4 menunjukkan bahwa terdapat hubungan yang signfikan antara kejadian diare dengan pengelolaan limbah $(P$ value $<0,05)$ dengan nilai

\section{PEMBAHASAN}

\section{Gambaran Kejadian Diare}

Berdasarkan hasil penelitian, terdapat $38,4 \%$ atau 68 orang responden yang mengalami diare dalam kurun waktu tiga bulan terakhir sejak pengam-bilan data. Kejadian diare dalam pene-litian ini diketahui dengan kuesioner berisi pertanyaan mengenai definisi diare. Masyarakat peternak sapi perah dan atau anggota keluarga dikatakan diare apabila mengalami kondisi buang air
$\mathrm{PR}=3,59$ yang berarti bagi peternak yang tidak melakukan pengelolaan limbah dengan baik berisiko 3,59 kali lebih besar untuk terkena diare.

besar lebih dari tiga kali dalam sehari dengan konsistensi tinja lembek atau cair (WHO, 2016 dan Kemenkes RI, 2011).

Kejadian diare yang dialami oleh masyarakat peternak sapi perah di Dusun Krajan Desa Kemiri adalah diare akut, yakni diare yang berlangsung singkat sekitar satu atau dua hari (United State National Library of Medicine, 2016), dengan salah satu gejala yakni adanya nyeri di bagian perut (Al-Gallas, dkk, 2007 dan Widoyono, 2008). 
Kejadian diare yang dialami oleh masyarakat peternak di Dusun Krajan Desa Kemiri merupakan kejadian diare tanpa disertai adanya penyakit lain seperti gastroenteritis akut, disenteri maupun kolera.

\section{Gambaran Kepadatan Lalat}

Hasil penelitian menunjukkan bahwa terdapat 17 responden yang memiliki kandang dengan kepadatan lalat sangat tinggi dan 35 responden dengan kepadatan lalat tinggi. Tingginya kepadatan lalat di Dusun Krajan Desa Kemiri dapat disebabkan karena adanya kandang sapi di lingkungan rumah dengan jarak kurang dari 10 meter (92\% responden), dan limbah ternak yang tidak dikelola dengan baik $(60,5 \%$ responden) sehingga mempermudah lalat untuk hinggap ke rumah penduduk.

Kepadatan lalat yang rendah (86 orang atau $48,6 \%$ responden) dan kepadatan lalat sedang (42 orang atau $22 \%$ responden) disebabkan karena di dalam konsentrat makanan yang diberi-kan kepada sapi mengandung bahan yang mampu mengurangi bau kotoran yang dihasilkan oleh sapi, sehingga ketertarikan lalat menjadi berkurang. Selain itu, pada beberapa kandang ditemukan adanya pembakaran rumput kering sisa makanan sapi. Pembakaran tersebut dapat menimbulkan asap. Pengasapan merupakan salah satu cara dalam usaha pengendalian lalat (Dewi, 2007).

\section{Gambaran Pengelolaan Limbah Ternak}

Sebagian besar rumah yang memelihara sapi perah tidak mengelola limbah ternaknya dengan baik (107 responden atau 60,5\% dari total 177 sampel). Banyaknya peternak yang tidak mengelola limbah ternaknya dengan baik ditinjau dari poin-poin penilaian penge-lolaan limbah ternak diantaranya jarak kandang dengan rumah, kondisi tempat penampungan kotoran ternak, kondisi saluran pembuangan air limbah ternak, pembersihan kandang, serta pengumpulan dan pemanfaatan limbah ternak.
Jarak kandang dengan rumah penduduk mayoritas kurang dari 10 meter. Sementara itu, tempat penampungan kotoran ternak $(85,3 \%)$ masih terdapat kontak dengan udara terbuka sehingga selain menimbulkan bau tidak sedap juga mengganggu kesehatan manusia (Widyastuti, 2013).

Kondisi saluran pembuangan air limbah milik mayoritas peternak tidak terpisah dengan air hujan $(67,2 \%)$ serta tidak kedap air $(75,1 \%)$. Hal tersebut dikhawatirkan menjadi penyebab perembesan air limbah ke lingkungan sehingga menimbulkan polusi serta menjadi tempat perkembangbiakan nyamuk dan lalat selaku vektor penyakit (Peraturan Menteri Negara Lingkungan Hidup Nomor 11 Tahun 2009 dan Hongkong Environmental Protection Department, 2016). Selain itu hanya 72 responden yang mengolah limbah ternak menjadi biogas dan pupuk kandang. Padahal pengolah limbah penting dilakukan untuk mengurangi jumlah limbah yang dibuang ke lingkungan (Abdurrahman, 2008).

\section{Hubungan Kejadian Diare dengan Kepadatan Lalat}

Analisis uji statistik hasil penelitian menggunakan chi square pada tabel 4 menunjukkan bahwa terdapat hubungan yang signifikan antara kejadian diare dengan kepadatan lalat sangat tinggi dan kepadatan lalat tinggi $(P$ value $<0,05)$. Selain itu, risiko untuk terkena diare semakin besar apabila kepadatan lalat semakin tinggi.

Lingkungan biologis seperti vektor penyakit dan keadaan lingkungan dengan sanitasi yang buruk mampu menyebabkan penyakit menular seperti diare (Lidya dan Muliani, 2010). Keadaan sanitasi yang buruk di Dusun Krajan disebabkan oleh tercemarnya lingkungan karena limbah ternak, padahal kotoran ternak adalah tempat perkembangbiakan lalat (Dewi, 2007). Lalat dapat membawa berbagai mikroba seperti Salmonella spp, Shigella spp, Vibrio cholerae dan E. Colii yang mampu mencemari makanan dan me- 
nyebabkan diare (Adler, 2010 dan Anitasari, 2008).

Hasil penelitian ini sejalan dengan penelitian Manulu, dkk (2012) mengenai hubungan tingkat kepadatan lalat (Musca domestica) dengan kejadian diare pada anak balita di pemukiman sekitar TPA sampah Namo Bintang. Hasil penelitian ini menunjukkan adanya hubungan antara kejadian dare dengan tingkat kepadatan lalat.

\section{Hubungan Kejadian Diare dengan Pengelolaan Limbah Ternak}

Analisis uji statistik dengan menggunakan chi square diperoleh hasil $p$ value $=0,00$, hal ini menunjukkan bahwa terdapat hubungan yang signifikan antara kejadian diare dengan pengelolaan limbah ternak pada peternak sapi perah di Dusun Krajan Desa Kemiri Kecamatan Jabung Kabupaten Malang. Adanya hubungan tersebut disebabkan karena 107 peternak atau 60,5 \% responden tidak melakukan pengelolaan limbah ternak dengan baik.

Lingkungan biologis seperti vektor penyakit tertentu dan keadaan lingkungan dengan sanitasi yang buruk mampu menyebabkan penyakit menular seperti diare (Lidya dan Muliani, 2010). Keadaan sanitasi yang buruk dapat disebabkan oleh tercemarnya lingkungan karena limbah ternak. Berdasarkan hasil observasi, mayoritas masyarakat peternak sapi perah di Dusun Krajan Desa Kemiri mengalirkan air limbah ternak (berupa sisa pencucian kandang maupun air kencing dan kotoran ternak yang sudah diencerkan) ke selokan dan langsung terbuang ke lingkungan tanpa pengolahan terlebih dahulu. Selain itu, masih banyak peternak yakni sekitar 67,2\% dari responden atau 119 peternak belum melakukan pemisahan saluran air limbah dengan saluran air hujan. 75,1\% responden atau 133 peternak juga belum membuat saluran limbah yang kedap air, sehingga perembesan air limbah ternak ke tanah sangat mungkin terjadi. Limbah ternak yang langsung dibuang ke lingkungan tanpa diolah terlebih dahulu dapat menyebabkan polusi udara, air dan tanah (Widyastuti, dkk, 2013).

Sebanyak $60,5 \%$ responden atau 107 orang peternak sapi perah di Dusun Krajan Desa Kemiri tidak melakukan pengelolaan limbah ternak dengan baik, padahal pada tanah dengan kandungan feses dan urin sapi antara 27$86 \%$ merupakan media paling baik untuk pertumbuhan dan perkembangbiakan larva lalat yang merupakan vektor diare (Nurtjahaya dalam Anitasi, 2008). Selain itu, mikroorganisme patogenik (penyebab penyakit) yang berasal dari limbah ternak dapat mencemari lingkungan. Salah satu

mikroorganisme tersebut adalah Salmonella $s p$ yang merupakan agen penyebab diare (Rachmawati dalam Widyastuti, dkk, 2013).

Penelitan dengan hasil yang sama dilakukan oleh Anitasari (2008) mengenai hubungan antara kondisi sanitasi kandang ternak dengan kejadian diare pada peternak sapi perah di Desa Singosari Kecamatan Mojosongo Kabupaten Boyolali menunjukkan adanya hubungan antara pemanfaatan limbah ternak dengan kejadian diare.

\section{KESIMPULAN}

Berdasarkan hasil penelitian, dapat diperoleh kesimpulan sebagai berikut (1) Angka kepadatan lalat disekitar kandang ternak sapi perah yang memiliki kepadatan sangat tinggi sebesar 9,6\% (17 resonden), kepadatan tinggi sebesar 19,8\% (35 responden), kepadatan sedang sebesar 22\% (39 responden) dan kepadatan rendah sebanyak 86 responden $(48,6 \%)$. (2) Peternak yang melakukan pengelolaan limbah dengan baik sebanyak 70 responden (39,5\%). (3) Sebanyak 38,4\% atau 68 keluarga peternak pernah mengalami kejadian diare. (4) Terdapat hubungan yang signifikan antara kejadian diare dengan kepadatan lalat tinggi dan sangat tinggi $(P$ value $=0,00)$, sehingga semakin tinggi kepadatan lalat, semakin ada hubungan yang signifikan dengan kejadian diare. (5) Terdapat hubungan yang signifikan antara 
kejadian diare dengan pengelolaan limbah $(P$ value $=0,00)$.

\section{SARAN}

Dengan memperhatikan hasil penelitian, pembahasan, dan kesimpulan, maka saran yang dapat diuraikan sebagai berikut. Dinas Kesehatan Kabupaten Malang dan Puskesmas Jabung sebaiknya melakukan upaya pengendalian dan pemberantasan lalat dari sumbernya, yakni wilayah peternakan sapi perah di Dusun Krajan Desa Kemiri Kecamatan Jabung. Selain itu upaya preventif untuk mencegah dan mengurangi diare juga perlu dilakukan, diantaranya meningkatkan promosi kesehatan seperti penerapan Perilaku Hidup Bersih dan Sehat (PHBS) dan melaksanakan kerjasama lintas sektoral dengan instansi terkait untuk mengendalikan limbah ternak agar tidak berdampak besar terhadap kesehatan lingkungan maupun masyarakat. Saran bagi Pemerintah Desa Kemiri yakni sebaiknya perlu mela-kukan kerjasama dengan instansi terkait untuk melaksanakan proses pengelolaan dan pemanfaatan limbah secara komunal dan terpadu. Masyarakat peternak sapi perah sebaiknya menerapkan PHBS dan meningkatkan kesehatan lingkungan rumah dan peternakan dengan cara mengelola dan memanfaatkan limbah ternak sapi perah serta tidak membuang limbah ke lingkungan.

\section{DAFTAR RUJUKAN}

Abdurahman, Deden. 2008. Biologi: Buku Pelajaran Bologi Kelompok Pertanian dan Kesehatan untuk Kelas XI SMK. Bandung: Grafindo Media Pratama.

Adler,Stefan Collinet. 2010. Environmental Indicators of Enteric Infections in a Rural Area and Urban Slum of Vellore, India. Boston: Tufts University.

Al-Gallas, Nazek, dkk. 2007. Etiology of Acute Diarrhea in Children and Adults in Tunis, Tunisia, with Emphasis on Diarrheagenic Escherichia coli: Prevalence,
Phenotyping, and Molecular Epidemiology. American Journal Tropical Medicine Hygiene, 77(3): 571-582.

Anitasari, Puji. 2008. Hubungan Antara Kondisi Sanitasi Kandang Ternak dengan Kejadian Diare pada Peternak Sapi Perah di Desa Singosari Kecamatan Mojosongo Kabupaten Boyolali Tahun 2008. Skripsi tidak diterbitkan. Fakultas Ilmu Kesehatan: Universitas Muhammadiyah Surakarta.

Dewi,Dian Indra. 2007. Lalat dan Kehidupannya. Balaba: Jurnal Litbang Pengendalian Penyakit Bersumber Binatang, 4(1): 18-19.

Hongkong Environmental Protection Department. 2016. Code of

Practice Livestock Waste Management. (Online), (http: //www.epd.gov.hk/epd/sites/defau lt/files/epd/english/environmentin hk/waste/guide_ref/files/all.pdf), diakses 17 Mei 2017.

Kementerian Kesehatan Republik Indonesia (Kemenkes RI). 2011. Situasi Diare di Indonesia. (Online), (http://www.depkes.go. $\mathrm{id} /$ download.php?file $=$ download $/ \mathrm{p}$ usdatin/buletin/buletin-diare.pdf), diakses 2 September 2016.

Lidya, Maryani dan Muliani Rizki. 2010. Epidemiologi Kesehatan: Pende-katan Penelitian. Yogyakarta: Graha Ilmu.

Manulu, Merylanca, dkk. 2012. Hubungan Tingkat Kepadatan Lalat (Musca domestica) dengan Kejadian Diare pada Anak Balita di Pemukiman Sekitar Tempat Pembuangan Akhir Sampah Namo Bintang Kecamatan Pancur Batu Kabupaten Deli Serdang Tahun 2012. Jurnal Lingkungan dan Kesehatan Kerja, 2(1): 1-10.

Peraturan Menteri Negara Lingkungan Hidup Nomor 11 Tahun 2009 tentang Baku Mutu Air Limbah Bagi Usaha dan/atau Kegiatan Peternakan Sapi dan Babi. 2009. Jakarta: Kementerian Lingkungan Hidup. 
Puskesmas Jabung Kabupaten Malang. 2014. Laporan Tahunan Puskesmas Jabung Tahun 2014.

Sugiyono. 2015. Metode Penelitian Kuantitatif, Kualitatif, dan $R \& D$. Bandung: Alfabeta.

United States National Library of Medicine. 2016. Diarrhea. (Online), (https://medlineplus.gov /diarrhea.html), diakses 13 November 2016.

World Health Organisation (WHO). 2016. Diarrhoea. (Online), (http://www.who.int/topics/diarrh oea/en/), diakses 2 September 2016.
Widyastuti, Fianda Revina, dkk. 2013. Upaya Pengelolaan Lingkungan Usaha Peternakan Sapi di Kawasan Usahatani Terpadu Bangka Botanical Garden Pangkalpinang. Makalah disajikan pada Seminar Nasional Pengelolaan Sumber Daya Alam dan Lingkungan 2013. Dalam Diponegoro University Institutional Library, (Online), (http:// eprints.undip.ac.id/40627/1/012_F ianda_Revina_Widyastuti. pdf), diakses 11 Januari 2017.

Wijayanti, Tri. 2008. Vektor dan Reservoir. Balaba: Litbang Depkes RI, 02(18): 18-19. 